\title{
The Implementation of Active Learning for Fifth Grade English Learner in Secondary School
}

\author{
${ }^{1}$ Mehmet Burçin Özkan $\quad{ }^{2}$ Tuğba Bademci-Kaydet
}

\author{
${ }^{1}$ English Teacher, Tepeköy İlokulu, ORCID NO: 0000-0002-2372-4269 \\ ${ }^{2}$ English Teacher, Mersin Tarsus Zühtü Günaştı Anadolu Lisesi, 0000-0002-7221-5516
}

Geliş: 16 Aralık 2019

Kabul: 31 Aralık 2020

Öz

Çalışma Mersin ili Yenişehir ilçesinde ortaokul düzeyindeki bir devlet okulunda yürütülmüştür. Çalışmamızda karma desen kullanılmıştır. Bu çalışmada Mersin ili Yenişehir ilçesinde bir devlet okulunda öğrenim gören 50 5. Sınıf öğrencisi yer almıştır. Çalışmada yer alan öğrencilerin $25^{\prime}$ 'i kız, 25'i erkektir. Çalışma yaklaşı 8 ay sürmüştür. Çalışmanın amaçları, öğrencilerin İngilizce konuşmayı aktif olarak derse katılarak ve deneyimleyerek öğrenmelerini sağlamaktır. Ayrıca, çalışmanın en önemli amaçlarından birisi İngilizceyi keyifli bir şekilde öğretmektir. Bu çalışma kapsamında araştırmacı, her hafta derste farklı bir etkinlik kullanarak öğrencilere İngilizce konuşmayı öğretmiştir. Bu dersler aktif öğrenme temellidir. Çalışmadan veri toplamak için nicel ve nitel yöntemeler kullanılmıştır. Bu yöntemler ön- konuşma testi, son-konuşma testi, ön- yarı yapılandırılmış görüşme, son yarı yapılandırılmış görüşme, gözlem raporu ve değerlendirme kontrol listesidir. Çalışmanın sonunda öğrencilerin İngilizce seviyelerinin yükseldiği konuşma testleri sonuçları ile ortaya konmuştur. Ayrıca, ön- yarı yapılandırılmış görüşme, son yarı yapılandırılmış görüşme, gözlem raporu ve değerlendirme kontrol listesi ile öğrencilerin aktif öğrenme yöntemi ile İngilizce dersine karşı motivasyonlarının ve isteklerinin genel olarak arttı̆ğ tespit edilmiştir.

Anahtar kelimeler: Aktif öğrenme, çoklu zekâ, deneyimle öğrenme, ortaokul öğrencileri

\begin{abstract}
The study was carried out in a public secondary school in Yenişehir district of Mersin province. The method of the study was Mixed Research Design. 50 students who studied in fifth grades in a public secondary school in Yenişehir district of Mersin province took place in this study. 25 of them were girls and 25 of them were boys. The study lasted about 8 months. The main aim of the study is to enable students to speak English by actively participating and experiencing. Moreover, one of the most important aims of the study is to teach English speaking in an enjoyable way. Within the scope of this study, the researcher taught English to the students using a different activity each week. The lessons focused on Active Learning method and its activities. Obtain the date of the study, qualitative and quantitative methods were used. These were pre-speaking test, postspeaking test, pre-semi structured interviews, post-semi structured interviews, observation reports and student evaluation check lists. According to the results of test, the levels of the students increased. Generally, it was observed that all students and their families were pleased with the activities. The semi-structured interviews were carried out on students to gather their ideas about the study. During the activities, observations were made, and an observation report was prepared by the researchers. According to the results of pre-semi structured interviews, post-semi structured interviews, observation reports and student evaluation check lists, it was determined that the motivation and willingness of the students towards English lessons increased.
\end{abstract}

Keywords: Active learning, multiple Intelligence, learning by experiencing, secondary students

\section{Introduction}

Throughout the history, English teachers tried different methods to attract the attentions of the students to the English teaching lessons. They always try new methods. Unfortunately, 
traditional methods are observed to be not very effective to attract the attentions of students who were born 21 st century as they were born in a computer age. The world in the computer is different from the real world. Everything is more colourful and enjoyable than real life. It is difficult for teachers to make them adapt into the lesson; therefore the teacher needs new methods. These methods need to be colourful and enjoyable. In this study, the researcher unites active learning and computer assisted language learning in English language teaching classroom.

Active learning is a method encourages students to be included into their learning environment. It is a new method which includes a lot of activities during the lesson. It means engaging students in an activity or task that will make the learner think. (Gholami et al., 2014) It is entirely with student-centred learning and they are both different learning methods (Alves, 2015). These methods help student learn better and enjoy the lesson. It is a useful method and effective learning. (Gholami et al., 2014)

Traditional lessons which have been the form of learning and teaching for decades turned out to be insufficient in providing learning opportunities to the students and teachers. (Er et al., 2012) therefore teachers need new attractive methods. These methods need to be colorful and enjoyable. It helps teachers to attract the attentions of students. Alves (2015) insisted that the right techniques deepened their learning, therefore teachers need to try different methods to attract all attentions of all students as their interest areas are different from each other. Students learn better in more in active learning environment than passive learning environment. Using active learning in English lesson makes learning environment enjoyable for students. Students become more willing to join the lesson. (Gholami et al., 2014) Active learning fulfils the needs of the new generation learners. (Er et al., 2012)

Alves (2015) suggested 40 these methods and they were productive for the students and it was worth trying them. I agreed him that these active methods were effective while teaching English. Compared to traditional methods, students enjoyed more. (Gholami et al., 2014). The group engaged in these techniques, was successful in enhancing reading comprehension achievement. (Er et al., 2012) In their study Mulatu and Bezabih (2018) states that according to the FL teachers active learning is a student-centred process, in this process students feel themselves confident, and teachers believe that active learning means practical way of teaching and learning process.

\section{Theoretical Framework}

\section{Active Learning}

Active learning is anything that students do in a classroom other than just passively listening to an instructor's lecture. It is a process whereby students are actively engaged in building understanding of facts, ideas, and skills through the completion of instructor-directed tasks and activities (Zewdu, 2017). There are various terms used to describe active learning and these include: student-centred learning, collaborative learning (team, peer or group learning), engaged learning, and participatory learning.

\section{Computer Assisted Language Learning}

Computer technology has an important place in education as well as in all other areas of life. It is more widely used in education day by day due to its flexibility and being able to appeal to the different senses of the students. Computer and computer applications, which enable students to prepare activities suitable for 4 language skills, are also prominent in foreign language education. For this reason, new applications and Web 2.0 tools are being produced day by day to be used in foreign language lessons. Garrett states this situation as "we have not 
only computers of almost incomprehensibly greater power and sophistication but also a far greater range of consumer technologies that can be harnessed for language teaching and learning." (Garrett, 2009, p. 719)

Multiple Intelligences

Multiple Intelligences: "Multiple Intelligences" Theory grew out of the work of Howard Gardner who challenged the too narrowly defined intelligence with his proposal of basic human intelligence types (linguistic, logical- mathematical, musical, spatial, bodily kinaesthetic, interpersonal and intrapersonal). Although originally started as 7 intelligences, an eighth intelligence "naturalistic intelligence" has been added to the list and now there is the possibility of a ninth intelligence "emotional intelligence" or "spiritual intelligence". Multiple Intelligences, as a theoretical construct, suggests that intelligence should be determined by measuring one's capacity for solving problems and fashioning products in a context-rich and naturalistic setting. (Chen \& Gardner, 2005) describe the types of intelligences as the following;

1. Linguistic intelligence, describes the ability to perceive and generate spoken and written language,

2. Logical-mathematical intelligence, involves the ability to appreciate and utilize numerical, abstract, and logical reasoning to solve problems,

3. Musical intelligence, entails the ability to create, communicate, and understand meanings made out of sound,

4. Spatial intelligence, refers to the ability to perceive, modify, transform, and create visual and/or spatial images,

5. Bodily-kinaesthetic intelligence, deals with the ability to use all or part of one's body to solve problems or fashion products,

6. Naturalistic intelligence, concerns the ability to distinguish among critical features of the natural environment,

7. Interpersonal intelligence, describes the ability to recognize, appreciate and contend with the feelings, beliefs, and intentions of other people,

8. Intrapersonal intelligence, involves the ability to understand oneself including emotions, desires, strengths, and vulnerabilities and to use such information effectively in regulating one's own life.

\section{Research questions of the study}

1) Does active learning method will increase the speaking levels of the students?

2) Does active learning method motivate the students toward English lessons?

\section{Methods}

This chapter describes the methodology of the study. It tells about the research design, participants, and procedure.

This study was an action research study. As to the circle of action research, the researcher determined the problems of the classes. The problems were having pre-judices toward English lessons and anxiety while speaking English language. Moreover, they did not have sufficient motivation toward English lessons, and they were not willing to speak during the English lessons Then, the researchers identified their participants and their research. It took 
place in the 5th class in a public secondary school in Yenişehir in Mersin. This study was consisted of 14 hours English lesson each week. This study lasted 8 months. The main of the study was to teach English to 50 fifth grade students studying in a public secondary school by active learning methods and its activities. These activities included games, materials, painting, making models and competitions. Before the study, the researchers made brainstorming together and they prepared a timetable according to English curriculums in secondary government schools. Every month, they made an activity related to the theme of the month. They made lessons plans to include active learning method activities. The teachers who were one of the researchers at the same time implemented the programme. During the study period, lessons were observed by the researcher using the observation report. Besides observation, to obtain ideas, attitudes, and feelings of students toward English lessons enriched with active learning methods, pre-speaking test, post-speaking test, pre-semi structured interview, postsemi structured interview and student evaluation check list were used. In acting part, the researchers collected data. Pre-speaking test were implemented before the study. After the 8month study period, post-speaking test were implemented. They had the same questions. They were implemented to see the difference between the English-Speaking levels of the students. In pre--semi structured interview students were asked about their preferences in English lessons. Post--semi structured interview was put into practice after the study period to learn about the good point of the study as to the students. Student evaluation check list included 5 Yes/ No questions. This data was considered quantitative as it included Yes/ No questions. While evaluating this data, Nominal Yes/No Scale was used. In observing part, they analysed the data. The study was qualitative and quantitative study. The rubric concluded five parts. They were "Content, Presentation Design, Speaking Skills, Creativity and Mechanic". Each part had 20 points and they totally made up 100 points. The researchers evaluated students' presentations according to rubric out of 100 .

\section{Aims}

This study aims to find out the effects of the method of active learning in English classes in fifth grades. This study argued that active learning had positive effects on the behaviours of the fifth-grade students towards English lessons.

In this study, researchers encouraged students to learn English with active learning methods. The teacher tried this different method and to attract the attentions of the students and motivate them toward English lessons.

In this study, researchers encouraged students to do speaking practice in English classes. Researchers created speaking activities in real life context. The teachers tried to improve students' productive skills with the active learning method.

\section{Participants}

The participants of the present study were 50 fifth grade students. 25 students were girls, and 25 students were boys. They were chosen according to the background information, ages, grades, and genders of them.

They were 10-11 years. 50 students joined this study from two classes. old. They were in the same secondary school which was a public school in Mersin. They had studied the secondary school for a year. Their common CEFR level was A1 according to the results of level tests carried out by the school. They took their English classes from the same participant English teacher. They have 14 English lesson hours per week.

Their English curriculum provided English lessons four skills integrated with the help of the active learning method. 


\section{Data Collection Tools}

In this study, pre-speaking test, post-speaking test, pre-semi structured interview, postsemi structured interview, observation report and student evaluation check list were used.

To evaluate data obtained from pre-semi structured interview, post-semi structured interview, observation report, content analysis and descriptive methods were used. To reflect quantitative data in check list, Nominal Yes/No Scale was used.

Pre-speaking test and post- speaking test were evaluated according to the rubric which was prepared by the researchers. The rubric concluded five parts. They were "Content, Presentation Design, Speaking Skills, Creativity and Mechanic". Each part had 20 points and they totally made up 100 points. The researchers evaluated students' presentations according to rubric out of 100 .

\section{1) Pre-Speaking Test}

Pre-Speaking test was implemented on 50 fifth grade students studying in a public secondary school in Mersin before the study. The researchers prepared 50 different speaking questions according to the curriculum of English in Fifth class in Secondary school and CEFR level was A1. They put them into ten colourful envelopes. Every envelope had five different questions. The students chose one envelope and answered five questions. The duration of prespeaking test was between 3 and 5 minutes for each student.

The researchers prepared speaking rubric including "Content, Presentation Design, Speaking Skills, Creativity and Mechanic" and they evaluated the answers according to the rubric and gave them the points out of 100 .

\section{2) Post-Speaking Test}

Post-speaking test was carried out on 50 fifth grade students studying in a public secondary school in Mersin at the end of the research which lasted 8 months. During the 8 month- period, the teachers gave 14 hour- English lessons enriched by active learning methods activities per week. The post-speaking test had the same questions as the pre-speaking test. The teachers used the same envelopes and the same speaking rubric to evaluate the tests. The duration of pre-speaking test was between 3 and 5 minutes for each student.

\section{3) Student Evaluation Check List}

The researcher gathered the data from Student evaluation check list which was created by the researchers themselves including Yes/ No questions. This data was considered quantitative as it included Yes/ No questions. While evaluating this data, Nominal Yes/No Scale were used. Students evaluation check list was put into the practice on 50 fifth grade students studying in a public secondary school in Mersin after the study to evaluate the project.

Student Evaluation Check List has 5 questions. Participants respond the questions; Is the English lesson different from English lesson in earlier years? Is the study useful? Are the activities useful? Is English Class enjoyable? Do you think that your level of English will improve during the year? Participants answered these questions as Yes or No. 
The check list was carried out on students in 5thgrades. It asked questions about their thoughts about English lessons enriched with active learning methods activities. The check list was sent to the students via Google Forms. It asked about their ideas about the lessons and their attitudes toward English lessons.

\section{4) Pre-Semi-Structured Interview of The Students}

Pre-Semi-Structured Interview was put into practice on 50 fifth grade students studying in a public secondary school in Mersin before the study. It asked about the preferences of the students in English lessons. Only one question is asked. This question is;

- What would you prefer in an English class?

\section{5) Post-Semi-Structured Interview of The Students}

Post- Semi-Structured Interview was put into practice on 50 fifth grade students studying in a public secondary school in Mersin after the study. It asked about the good point of the study as to the students. All students were asked only one questions. This question is;

- What is the good point of the study?

\section{6) Observation Report}

While making observation, the researchers needed an observation report to be objective and to focus on the aim of the study. Observation report was prepared by the researchers. The researchers used a student observation report which had 6 parts.

These are Purpose of Observation, Context of Observation, Main Findings, Conclusions/Interpretations/Recommendations: Another Observation Needed, Observation Notes. The researchers wrote observation reports in every lesson to take notes feelings and behaviours of the students. The researchers observed 50 fifth grade students studying in a public secondary school in Mersin every lesson. To evaluate data obtained from observation report, content analysis and descriptive methods were used.

\section{Procedure of The Study}

To carry out the study, the consent forms were taken from the families. School administration gave permission for the study.

\section{Findings}

\section{1) The Result of Pre-Speaking Test}

Pre-Speaking test was implemented on 50 fifth grade students studying in a public secondary school in Mersin before the study. 


\section{Table 1.}

The Result of Pre-Speaking Test

\begin{tabular}{ll}
\hline Type of Test & Percentages \\
\hline Pre-Speaking Test & $\% 66$ \\
\hline
\end{tabular}

The average of the result of pre-speaking test was 66 points out of 100 points which was very low and showing that the English level of the students was A1 according to CEFR.

\section{1) Post-Speaking Test}

Post-speaking test was implemented on the target group at the end of the research which lasted 8 months. During the 8 month- period, the teachers gave 14 hour- English lessons enriched by active learning methods activities per week.

\section{Table 2.}

Post-Speaking Test

\begin{tabular}{ll}
\hline Type of Test & Percentages \\
\hline Post-Speaking Test & $\% 87$ \\
\hline
\end{tabular}

The post-speaking test had the same questions as the pre-speaking test. The average of the results of post-speaking test was 87 points out of 100 points. There was 32 percentage success difference between two tests. This showed the improvement in English speaking levels of the students.

\section{2) Student Evaluation Check List}

Students evaluation check list was put into the practice on the students after the study to evaluate the project. There were 5 questions in the Check List. 5 of them were Yes/ No questions. The results were evaluated by Nominal Yes/No Scale.

Table 3.

Nominal Yes/No Scale of Check lists

Student evaluation check list results

\begin{tabular}{lll}
\hline Questions & Yes & No \\
\hline 1) Is the English lesson different from English lesson in earlier years? & $\% 87$ & $\% 13$ \\
2) Is the study useful? & $\% 90$ & $\% 10$ \\
3) Are the activities useful? & $\% 90$ & $\% 10$ \\
4) Is English Class enjoyable? & $\% 92$ & $\% 8$ \\
5) Do you think that your level of English will improve during the year? & $\% 92$ & $\% 8$ \\
\hline
\end{tabular}

87 percentages of the students answered "Yes" to the first question which "Is the English lesson different from English lesson in earlier years?" They thought that English lesson 
enriched with active learning methods activities were different from their classic English lessons.

90 percentages of the students thought that the study was useful. By saying yes to the second question which was "Is the study useful?", they supported the active learning method activities used in English classes.

90 percentages of the students found the activities useful. This meant that students found the activities which were songs, games, materials, competitions beneficial for them.

92 percentages of the students thought that their English class was enjoyable, and this proved that the active learning method activities enriched the English class and they mad e the lessons enjoyable.

92 percentages of the students thought that their level of English improved during the year. Most of the students agreed that their level improved thanks to the active learning activities implemented during their lessons.

\section{3) Content Analysis of All Qualitative Data}

The evaluation check list, post-semi structured interview and observation report were qualitative data of the study. The analysis of all qualitative data was evaluated with content analysis. There were 3 themes to reflect all data collected during the study. These were "Willingness of the students", "Enjoyment of the lessons", "The effects of games and activities"

Table 4.

Contetnt Analysis results

Themes
Willingness of the students
Enjoyment of the lessons
The effects of games and activities

\section{a) Willingness of the students}

The results of student evaluation check list, post-semi structured interview and observation report showed that students were willing to join English lessons enriched with the active learning methods. They were willing to sing songs and play games. They joined the lessons willingly. If they could not join the lesson, they got upset. They felt happy in the lessons. They wanted to go on activities in the following years.

In Pre-Semi-Structured Interview, only one question which is "What would you prefer in an English class?" is asked. This question revealed the preferences of the students towards to English lessons. The answers of four students indicated that they were willing to join the lessons.

"I never want a lesson without any games and any activities."

"The English lesson without games is very boring."

"I get bored in the English lesson without games."

"The English lesson without games is bad." 
Post- Semi-Structured Interview asked about the good point of the study as to the students. The question was "What is the good point of the study?" 2 students expressed that they were eager to take place in the lessons.

"I learn English better."

"It made me happy."

According to the observation report, students were willing to play games again and again. They felt happy when their products were exhibited on bulletin board and in the school. They were willing to sing a song and join the lessons. The researchers emphasized on the willing of the students by expressing that they were happy when their products were hung on a bulletin board. They were happy when their products were exhibited in the school. They joined the lesson willingly and happily. When there was no teacher in the class, they got upset. When the lesson was cancelled or delayed, they got sad.

\section{b) Enjoyment of the lessons}

The results of student evaluation check list, post-semi structured interview and observation report revealed that they found English lessons enriched with active learning methods enjoyable and fun. They expressed that they had a lot of fun during the lesson and the activities were very entertaining.

The answers to the questions of Pre-Semi-Structured Interview showed that the preferences of the students towards to English lessons. 3 students expressed their enjoyment in the lessons. "I want an enjoyable lesson."

"I want to have a fun."

"We both have fun and learn thanks to the games."

Post- Semi-Structured Interview asked the question was "What is the good point of the study?" to obtain the ideas of the students about the good point of the study.4 students enjoyed the lesson and they mentioned this in the post semi-structured interview.

"The activities were very entertaining and instructive."

"We have very enjoyable activities. We learn activities and songs."

"English lesson is very nice, and it has got lots of fun. I love it very much."

"It is very nice, and it is fun."

While making observation, the researchers wrote an observation report. The sentences which were "They were happy and willing to sing a song on the stage." and "They watched their videos happily." showed the enjoyment of the students in the lessons.

\section{c) The effects of games and activities}

The results of student evaluation check list, post-semi structured interviews and observation reports highlighted that the students wanted to play games again and again. This showed that the games had positive effects on the students. They emphasized that they both had fun and learn thanks to the games. This indicated that the games encouraged the students to learn English. They stressed the importance of games and activities saying that they love activities and they made nice activities which they loved them. Moreover, they had very enjoyable activities and they learnt activities and songs every week. They expressed that they learnt better when they did the activities. The students emphasized that the activities were very entertaining and instructive. These proved that the activities had positive effects on their English learning. 
The answers to the questions of Pre-Semi-Structured Interview revealed that the preferences of the students towards to English lessons. 2 students showed their preference of games and activities.

"I want games."

"I want activities."

"What is the good point of the study?" was asked in Post- Semi-Structured Interview to get the ideas of the students about the good point of the study. 4 students expressed their ideas about games and activities.

"I love activities."

"We make very nice activities. I love it very much."

"I learn better when we do these activities."

"I like every activity very much. I want it to continue in 6 th and 7 th grade."

The researchers wrote observation reports in every lesson to take notes feelings and behaviours of the students toward the games and activities of the study. She highlighted their preference of games by saying that they wanted to play games again and again.

\section{Discussion and Conclusion}

The results of this study were composed of two parts, qualitative and quantitative. Most of the results were qualitative based on pre-semi structured interview, post-semi structured interview, check lists and observation report. The results of post-test, and check list were quantitative. With the help of pre-semi structured interview, post-semi structured interview, check list and observation report, the attitudes of students towards to English Lessons enriched with active learning method activities were obtained. With the help of the speaking tests, English speaking levels of the students will be analysed.

This study aimed at finding answers to two research questions:

A) Does active learning method will increase the speaking levels of the students?

B) Does active learning method motivate the students toward English lessons?

For the first question, a speaking test was created by two researchers according to CFER. The test included 50 CFER A level different questions dividing into 10 groups. Each student was asked 5 questions. Firstly, this test was carried out on 50 fifth grade student studying in a public secondary school in Mersin as pre-speaking test in September. They took 14 English lesson hours enriched with active learning Method per week for 8 months. In June, after the treatment, a post-test was administered out on the same students. The average of the results of pre-speaking test was 66 points out of 100 points and the average of the results of post-speaking test was 87 points out of 100 points. The difference was 21 points between pre-speaking test and post-speaking test. The results of these speaking test show that English lesson enriched with active learning had positive effects on English speaking skills of the target group. In this study, it was found out that English speaking levels of the students increased. Likewise, the results of this study also confirm those conducted by Zewdu (2017) who studied active learning in Teaching English Language Support Courses to First-Year Students in Some Ethiopian Universities and Er et al., (2012) who studied The Effects of Active Learning On Foreign 
Language Self-Concept and Reading Comprehension Achievement in the sense that English lesson enriched with active learning created positive impact in the language classroom and active learning practices created a positive effect on the experiment group students.

For the second question "Does active learning methods motivate the students toward English lessons?", the results were obtained from pre-semi structured interviews, post-semi structured interviews, observation reports and student evaluation check list.

The analysis of all qualitative data was evaluated with content analysis. There were 3 themes to reflect all data collected during the study. These were "Willingness of the students", "Enjoyment of the lessons", "The effects of games and activities" These three themes were positive, and they reflected the positive effects of games and activities on English lessons.

Students answered 5 questions in the student evaluation check lists. According to the results of student evaluation check lists, 87 percentages of the students answered "Yes" to the first question which "Is the English lesson different from English lesson in earlier years?" They thought that English lesson enriched with active learning methods activities were different from their classic English lessons. This showed that active learning activities made differences in English lessons. 90 percentages of the students thought that the study was useful. By saying yes to the second question which was "Is the study useful?", they supported the active learning method activities used in English classes. The study had positive effects on the ideas of the students. 90 percentages of the students found the activities useful. This result is similar to the study of Ateka's . Ateka (2003) states that the notable points of the games are motivation of students, stress and enabling students to acquire new knowledge using real communication or interact with classmates who give students a stronger impression. This meant that students found the activities which were songs, games, materials, competitions beneficial for them. Komur, Sarac \& Seker's (2005) have similar results in their studies. According to Komur, Sarac $\&$ Seker's (2005) ideas about education, students could face many obstacles while experiencing learning FL process, so they need to use different materials such multimedia devices as especially songs. Students emphasized that the activities were beneficial. 92 percentages of the students thought that their English class was enjoyable, and this proved that the active learning method activities enriched the English class, and they made the lessons enjoyable. 92 percentages of the students thought that their level of English improved during the year. Most of the students agreed that their level improved thanks to the active learning activities implemented during their lessons.

The results of student evaluation check lists showed that students had positive attitudes toward English lessons enriched with active learning methods activities. Most of the students supported the study by finding the study and activities useful and beneficial. Almost all the students found that the lessons enjoyable. Moreover, almost all the students thought that the study improved their English-speaking level of the students.

The results of the pre-semi-structured interviews of the students indicated that students wanted enjoyable activities. They wanted games and activities. They did not want any homework. The pre-semi-structured interview of the students revealed that students decided what would motivate them toward English lessons. They reached an agreement on games and activities. The post-semi-structured interview of the students revealed that students thought that the activities were nice and fun. While they were learning English, they had fun. They enjoyed the lesson so much that they wanted to go on doing activities in following years. They felt happy while playing games. They loved English lessons and They learnt better. The students expressed their fun, enjoy, happiness and willingness toward English lessons enriched with 
active learning activities so this proved that active learning methods motivated the students toward English lessons.

The results of the observation reports highlighted that students were happy when they had English lessons. They were willing to join the activities and play games. They were motivated to learn English.

Zewdu (2017) had similar conclusions with this study emphasizing that students and instructors in the study thought that active learning and student-centred approaches were very important and the successful implementation of active learning in the EFL classroom made attitudinal changes in both instructors and students.

To sum up; active learning methods motivated the students toward English lessons.

\section{Suggestions}

This study was limited to 5th grade students so there is no chance to compare two different classes with different background, different ages, different cities, different countries, or different levels. It could be implemented in different socio-economic groups.

Active Learning methods was carried out to develop the speaking skills of the students, however, it could be implemented in other 3 skills which are listening, witing and reading.

This method was used in just fifth grades in a public school. It can be disseminated to other secondary schools. This method can be used in primary school levels or other secondary school levels. This method can be used in other lessons such as Math or science. An active learning study plan can be prepared for all English Language Learning Levels.

The Implementation of Active Learning was a short-term study as it was carried out a term however, this could be carried out as a long-term study.

\section{References}

Alves M. (2015). Ways to Apply Active Learning in the College ESL Classroom: The Old, The New, and Experiments in Teaching Techniques for Teaching with Active Learning

Atake, K. (2003). Using Games to Teach English in Japanese Junior High School. Retrieved November 3, 2009, from ERIC database. (ERIC Document Reproduction Service No. ED479748).

Attaran A., Gholamı V. \& Moghadda M. M. (2014). The Effects of Active Learning on Foreign Language Self-Concept and Reading Comprehension Achievement

Chen, J-Q., \& Gardner, H. (2005). Assessment based on multiple intelligences theory. In D. P. Flanagan (Ed.), Contemporary Intellectual Assessment: Theories, Tests, and Issues (77-102). New York: Guilford Press.

Er M., Altunay U. \& Yurdabakan İ. (2012). The Effects of Active Learning on Foreign Language SelfConcept and Reading Comprehension Achievement

Eslit E. R. (2017) Computer Assisted Language Teaching: Learning without Dust.

Garrett, N. (2009). Computer-assisted language learning trends and issues revisited: Integrating innovation. The modern language journal, 93, 719-740. 
Gholami, V., Moghaddam, M. M., \& Attaran, A. (2014). Towards an interactive EFL class: Using active learning strategies. The Clarion-International Multidisciplinary Journal, 3(2), 67-74.

Gündüz N. (2005) Computer Assisted Language Learning. Journal of Language and Linguistic Studies, $1(2),-$

Kitaw, Y. Z. (2017). Active learning in teaching English language support courses to first-year students in some Ethiopian universities (Doctoral dissertation).

Komur,S. Gursan, S. Seker, H. ( 2005) Teaching English Through Songs. Muğla University Social Sciences Journal, 15,109-118

Mulatu, M., \& Bezabih, W. (2018). Perceptions and practices of EFL teachers in implementing active learning in English classes: the case of three selected secondary schools in Dawro zone, SNNPRS, Ethiopia. International Journal of Education, 10(2), 88-94.

Zewdu K.Y. (2017) Active Learning in Teaching English Language Support Courses to First-Year Students in Some Ethiopian Universities 